\title{
The Fiduciary Duties of Directors of the Companies Facing M\&As in Delaware and Japan*
}

\section{Hidefusa lida}

Associate Professor, Graduate School of Law, Kobe University.

\begin{abstract}
This paper studies the relationship between the Revlon duties and the principle of maximizing shareholders' interests, and its position under the systems of Corporate Law, and then identifies the characteristics of relevant laws in Japan and Delaware. When considering the duties of directors of target companies regarding the fairness of the sale price, the right approach is to discuss how to deal with conflicts of interest and the final-period problem as issues specific to the sale of companies, rather than considering the issue based on deduction from the principle of maximizing shareholders' interests. There are two prominent features of relevant Japanese laws with respect to judicial examination of the duties of directors regarding the appropriateness of the sale price: (1) respect for shareholders' intentions and (2) the approach of paying attention to the price itself, rather than the process of mergers and acquisitions. Among background factors is a consistency with related systems such as regulation on transactions involving conflicts of interest and regulation on issuance of new shares in Corporate Law. Therefore, in order to require revision of the duties of directors of target companies, it is necessary to present a package of reforms regarding relevant systems as a whole.
\end{abstract}

Keywords: corporate governance, mergers and acquisitions, duties of directors

\section{Introduction}

Facilitating long-term shareholders' value is one of the hottest issues in corporate governance all over the world. ${ }^{1}$ This issue is not foreign to Japanese corporate law, although the debate on it is discussed especially in the United Kingdom and the United States. Even in Japan, the principle of maximizing shareholders' long-term, rather than short-term, interests is basically valid. ${ }^{2}$ Most corporate law scholars in Japan believe that the director's fiduciary duty is for implementing the corporation's goal to maximize shareholders' interests. ${ }^{3}$

In the debate on corporate governance, it is widely believed that facilitating short-term value at the expense of long-term value is inappropriate. However, a set of directors' duties called "Revlon duties" seems to mandate directors to focus on such short-term shareholders'

\footnotetext{
* This work was supported by JSPS KAKENHI Grant Number 25780070, 26285021.

${ }^{1}$ See, e.g., Roe (2013) and Bebchuk (2013).

2 Ochiai (1998) at 24.

3 See, e.g., Ochiai (1998) at 23.
} 
interests. This is one of the most well-known judicial doctrines in Delaware, and it requires the directors of a company facing a merger and acquisition (M\&A) to obtain the best price which is reasonably available. The conduct of such directors is reviewed by the court under a standard called the "Revlon standard," which asks if the directors acted reasonably in order to obtain the best price. This doctrine appears to require directors to maximize shareholders' short-term interests, rather than to pay attention to their long-term interests.

Of course, this doctrine is valid in Delaware, not in Japan. But, this is not entirely foreign to Japan's corporate law because the situation surrounding takeovers is becoming similar to that in Delaware. ${ }^{4}$ In fact, Shirai (2013a), for example, advocates that Japan's corporate law should import the Revlon standard. ${ }^{5}$ Furthermore, Tokyo High Court, in the management buyout (MBO) case, held that directors have, as part of the duty of care, an obligation to transfer "fair corporate value" to shareholders. "Fair corporate value" means the sum of the corporate value before $\mathrm{MBO}$ and the premium, to be given to shareholders, which is part of the corporate value to be increased by MBO. It is very similar to the concept of Revlon duties ${ }^{7}$ although the standard Tokyo High Court applied is not as restrictive as the Revlon standard. ${ }^{8}$

Regarding the fair price, what the fiduciary duties of directors of companies facing M\&As should be depends on two issues. The first issue is how we perceive the principle of maximizing shareholders' interests. Some lawyers ${ }^{9}$ and scholars $^{10}$ in Japan argue that the director's duty is toward the corporation itself, but not toward shareholders, because the Companies Act of Japan provides that directors must perform their duties for the corporation, ${ }^{11}$ and that, therefore, adopting duties like Revlon duties would be difficult. The other issue is whether the director's duty is only to maximize the interests of shareholders as a whole. If the answer to this question is no, then, such a principle is not an obstacle to assuming that the director's duty is to obtain a fair price for shareholders. If so, we should directly argue what the director's duty should be without paying too much attention to the principle of maximizing shareholders' interests.

In this paper, I approach these issues with comparative law analysis. This paper first analyzes the relationship between Revlon duties and the principle of maximizing shareholders' interests in Delaware, and the rationale of Revlon duties in the system of Delaware's corporate law (Section II). Then, I compare Japanese law with Delaware law in order to obtain a viewpoint to comment on the current differences between these two legal systems (Section III). Section IV concludes the discussion.

The contribution of this paper is two-fold. Firstly, this paper clarifies the director's duty

\footnotetext{
${ }^{4}$ See Tanaka (2012) at 379.

${ }^{5}$ However, Iwakura and Ishikawa (2010) disagree with importing Revlon duties because they do not match Japanese law.

${ }^{6}$ Anonym v. Reins International Inc., 2190 Hanrei Jiho 96 (Tokyo High Ct., Apr 17, 2013).

${ }^{7}$ Iida (2014b) at 23.

${ }^{8}$ See Shirai (2013b) at 51.

9 See Iwakura and Ishikawa (2010) and Ohta and Yano (2010).

${ }^{10}$ See Yanaga (2013, p.3), Saito (2014, p.19) and Kawashima (2014, pp.34-35).

${ }^{11}$ Sec. 355 of Companies Act of Japan.
} 
in the M\&As. Secondly, this paper clarifies the meaning of the principle of maximizing shareholders' interests. These points are unclear, at least in Japan.

\section{Literature on the Revlon Standard}

\section{II-1. Overview of the Revlon Standard ${ }^{12}$}

\section{II-1-1. What the Revlon Standard Is}

In 1986, the Delaware Supreme Court held that " $[\mathrm{t}]$ he directors' role changed from defenders of the corporate bastion to auctioneers charged with getting the best price for the stockholders at a sale of the company"13 in the case where "it became apparent to all that the break-up of the company was inevitable." "This holding is called the "Revlon duties" or "Revlon standard."

Delaware Supreme Court calls "[t]he duty to seek the best available price... when a company embarks on a transaction - on its own initiative or in response to an unsolicited offer-that will result in a change of control" Revlon duties. ${ }^{15}$ Delaware Chancery Court held that "[r]ather than changing the duties directors owe to stockholders, Revlon changes the level of scrutiny under which this Court reviews change-of-control transactions."16 The court applying the Revlon standard "should be deciding whether the directors made a reasonable decision, not a perfect decision."17 The Revlon standard "is a "middle ground" between deference to the board under the business judgment rule and skepticism toward the board under entire fairness review."18

\section{II-1-2. When the Revlon Standard Is Applied}

The Revlon standard is applied at least in the following three situations: "(1) when a corporation initiates an active bidding process seeking to sell itself or to effect a business reorganization involving a clear break-up of the company; (2) where, in response to a bidder's offer, a target abandons its long-term strategy and seeks an alternative transaction involving the break-up of the company; or (3) when approval of a transaction results in a sale or change of control."19 (Citation and emphasis omitted).

Manesh (2014, p. 33) classifies such cases from the viewpoint of the type of the consideration paid in the M\&As as following: When cash is used as the consideration, the Revlon standard is applied. When the target company is sold for the publicly traded stock of the acquirer, the Revlon standard is not applied. ${ }^{20}$ However, when the acquirer has a controlling

\footnotetext{
${ }^{12}$ This section owes much to Manesh (2014).

${ }_{13}$ Revlon, Inc. v. MacAndrews \& Forbes Holdings Inc., 506 A.2d 173, 182 (Del. 1986).

${ }^{14}$ Id.

${ }^{15}$ Lyondell Chem. Co. v. Ryan, 970 A.2d 235, 242 (Del. 2009).

${ }^{16}$ Koehler v. NetSpend Holdings Inc., Civil Action No. 8373-VCG, 2013 WL 2181518, at*11 (Del.Ch. May 21, 2013)

17 Paramount Communications v. QVC Network, 637 A.2d 34, 45 (Del. 1994).

${ }^{18}$ Koehler v. NetSpend Holdings Inc., Civil Action No. 8373-VCG, 2013 WL 2181518, at*11 (Del.Ch. May 21, 2013).

${ }^{19}$ Arnold v. Soc'y for Sav. Bancorp, Inc., 650 A.2d 1270, 1290 (Del. 1994).
} 
shareholder, the Revlon standard is applied even in the cases where the stock is used as the consideration. ${ }^{21}$ When the mix of cash and stock is used, the Revlon standard is applied in the cases where the ratio of the cash is high, but not in the cases where the ratio of the cash is low.

\section{II-1-3. Enforcement of the Revlon Duty}

When Revlon appeared, the directors might have been held liable to compensate damages if they had breached the fiduciary duties. However, after the Delaware General Corporation Law introduced Section 102(b)(7), which exculpates directors without bad faith from the liability to compensate damages, directors are highly unlikely to be imposed with such liability because of breaching Revlon duties. So, nowadays, the enforcement of Revlon duties is virtually only through equitable remedies such as injunction. However, the court rarely enjoins the mergers due to the breach of the Revlon duties. In sum, the court seldom gives the remedy to shareholders in cases where the plaintiffs allege that the directors breached Revlon duties. $^{22}$

\section{II-2. Overview of Discussion}

This section reviews the recent discussion on Revlon duties. On the one hand, Gevurtz (2013) argues that the Revlon standard is not necessary because the other director's duties adequately work. Johnson \& Ricca (2014) criticize the Revlon standard because it emphasizes the short-term interests. On the other hand, Laster (2013) and Bainbridge (2013) argue that the Revlon standard is necessary. They claim that the Revlon standard is useful for coping with problems arising from conflicts of interest and the final-period problem, and that the scope of Revlon standard application should be revised from the viewpoint of dealing with these problems. However, Gevurtz (2013) demurs at their suggestion to rationalize the Revlon standard from this perspective.

\section{II-2-1. The Relationship Between the Revlon Duty and the Principle of Maximizing Share- holders' Interests}

\section{(1) When the Break-up of the Company is Inevitable}

It is meaningless to increase the long-term shareholders' interests, which is the goal of the principle of maximizing shareholders' interests, when the break-up of the company is inevitable, as in the first and second situations in II- $1-2,{ }^{23}$ if the directors decide to stop managing a company as a going-concern. It is rational for directors to decide to break up the company if they think that the return for shareholders from the break-up of the company is higher than that from keeping the company managed as before. In this break-up case, the

\footnotetext{
${ }^{20}$ Paramount Communications, Inc. v. Time, Inc., 571 A.2d 1140 (Del. 1989).

${ }^{21}$ Paramount Communications v. QVC Network, 637 A.2d 34 (Del. 1994).

22 Johnson and Ricca (2014) at 205-215.

${ }^{23}$ See supra note 19 and accompanying text.
} 
principle of maximizing shareholders' interests also should require the directors to focus on increasing the short-term interests, or sale price. Otherwise, the directors' efforts to maximize shareholders' interests in the ordinary day-to-day management would be spoilt. Furthermore, as Gevurtz (2013) indicates, ${ }^{24}$ the directors in this case are prohibited from pursuing the long-term shareholders' interests because long-term shareholders' interests, by definition, do not exist in this case. Therefore, Revlon duties and the principle of maximizing shareholders' interests are compatible because they are applied in different cases. Revlon duties require the directors to obtain the best price, which is not prohibited by the principle of maximizing shareholders' interests in the case of the break-up of the company. In sum, the principle of maximizing shareholders' interests, which generally requires the directors to maximize the long-term value, transforms into a principle that requires the directors to maximize the short-term interests if the break-up of the company is inevitable.

\section{(2) Cases Other Than the Break-up of the Company}

The Revlon standard is also applied in cases other than the break-up of a company. Because the company remains as a going concern after the transaction in these cases, we cannot ignore the long-term value. Therefore, I disagree with the argument of Laster (2013) that the Revlon standard, which focuses on short-term interests, should be applied to all of the negotiated acquisition cases. ${ }^{25}$

But, at the same time, I do not agree with Johnson and Ricca (2014), who criticize the Revlon duties because it requires the directors to maximize the short-term interests. ${ }^{26}$ They examine it from the viewpoint of the long-term value: the goal of the directors should be to obtain the best long-term shareholders' interests. If the directors obtain the best long-term value by selling the company, they must choose the acquirer who offers the highest price, which is, by definition, the way to obtain the best long-term shareholders' interests. ${ }^{27}$ However, I believe that the "shareholder" has two different meanings in this argument. One is the current shareholder who receives the sale price. The other is the future shareholder who is the acquirer paying the acquisition price. It means both the current and future shareholders in the sense of the principle of maximizing shareholders' interests; but, it means only the current shareholders in the sense of obtaining the highest price for shareholders. Thus, their argument that choosing the acquirer to offer the highest price is, by definition, the way to obtain the best long-term shareholders' interests is not necessarily true. Of course, some might argue that those paying the highest price are those who use the object most efficiently. If so, the acquirer who pays the highest price would manage the target company most efficiently and, thus, maximize the interests of future shareholders. But, this logic is not always true, either. The highest bidder might offer the highest price not because it manages the target company most efficiently, but because it gains a benefit by preventing a rival who would

\footnotetext{
${ }^{24}$ Gevurtz (2013) at 1530, 1546-49.

${ }^{25}$ Laster (2013) at 53.

${ }^{26}$ See Johnson and Ricca (2014) at 219-20.

27 Johnson and Ricca (2014) at 220-25.
} 
possibly manage the target company most efficiently. ${ }^{28}$

In sum, Revlon duties are not necessarily consistent with the principle of maximizing shareholders' interests. Focusing on short-term shareholders' interests in M\&As is related to the directors' ordinal duty to maximize the long-term value because M\&As should be implemented if and only if such transactions increase the long-term corporate value. However, Revlon duties are not in accordance with the principle of maximizing shareholders' interests.

\section{II-2-2. Rationale of the Revlon Standard}

Focusing on short-term interests is not necessarily consistent with the principle of maximizing shareholders' long-term value, but this is not the only reason why the literature criticizes the Revlon standard. Actually, Johnson and Ricca (2014) suggest that the Revlon standard should be abolished, although even they do not deny the proposition that the directors should sell the company to the acquirer who offers the highest price if selling the company is necessary to increase the long-term value. However, Laster (2013) and Bainbridge (2013) justify the Revlon standard from the viewpoint of dealing with conflicts of interest and the final-period problem, which are serious issues involved in M\&As, although Gevurtz (2013) disagrees with this argument. At any rate, in this debate, the issue does not concern the propriety of focusing on short-term interests, but concerns the necessity of a special standard to tackle the problem of conflicts of interest and the final-period problem. Thus, this section considers these problems.

\section{(1) Direct Conflicts of Interest}

The degree of conflicts of interest depends on the types of cases. The interests of directors and managers directly conflict with those of shareholders in cases of MBO because the buyer-managers want to buy the company by paying as low an acquisition price as possible, while the seller-shareholders want to sell their shares at the highest price. The literature agrees with the existence of this kind of direct conflicts of interest. Even Gevurtz (2013) suggesting to abolish the Revlon standard does not suppose that the business judgement rule is applied in the case with direct conflicts of interest.

What the scholars disagree on is the standard to review such direct conflicts of interest in M\&As. Gevurtz (2013) argues that the traditional duty of loyalty is sufficient as the standard for tackling this problem and, thus, the Revlon standard is not necessary. On the other hand, Laster (2013) and Bainbridge (2013) argue that the Revlon standard is useful for dealing with this problem, but that the traditional duty of loyalty is not. Both arguments suppose that the business judgment rule is not directly applied to M\&As with direct conflicts of interest such as MBOs. They do not argue that the directors' decision should be given deference in such transactions. Under the traditional framework of the duty of loyalty, the business judgment rule is applied only if all of the material facts regarding the conflicts of

\footnotetext{
${ }^{28}$ See Miller (2013).
} 
interest are disclosed to the board of directors and if the board of directors agrees with the transaction. ${ }^{29}$ Under the Revlon standard, the question is whether the directors obtain the highest price reasonably available. Both frameworks accord in that the business judgement rule is not directly applied and that the process of the transaction is weighed in reviewing directors' conduct.

\section{(2) Potential Conflicts of Interest and the Final-Period Problem}

Both views differ in the cases of potential conflicts of interest. Potential conflicts of interest are found in cases where the directors prioritize their own personal interests and do not seriously negotiate the sale price for shareholders. For example, the directors might choose the acquirer not because she offers the highest price to shareholders, but because she offers the job position of executive to the directors of the target company even if the price is not the highest. ${ }^{30}$

Laster (2013) argues that the Revlon standard should be applied to all of the friendly M\&As because such a problem of potential conflicts of interest always occurs in such M\&As. ${ }^{31}$ First, Laster (2013, pp. 14-15) indicates that the Delaware Supreme Court in Revlon mentioned the factors showing conflicts of interest as follows: the CEO of the target company felt antipathy toward the CEO of the hostile bidder, ${ }^{32}$ the directors of the target company might have chosen the acquirer not because they prioritize shareholders' interests, but because they prioritize debt holders' interests, which boils down to benefiting the directors by preventing debt holders from filing a lawsuit against them. ${ }^{33}$ Second, he claims that because the situation in which the directors of the target company facing M\&As has a typical "final-period problem," 34 the directors apt to behave opportunistically, and, therefore, the Revlon standard should be applied in friendly M\&As. ${ }^{35}$

Bainbridge (2013) claims that the Revlon standard should be applied to cases where there are potential conflicts of interest and a deterrent mechanism (such as product markets and executive markets) other than law does not prevent directors from opportunistic behavior. Like Laster (2013), Bainbridge (2013) indicates that negotiated M\&As entail the problem of potential conflicts of interest. ${ }^{36}$ Bainbridge (2013) also indicates that the M\&As entail the final-period problem, but his discussion is a little different from Laster (2013). Bain-

\footnotetext{
${ }^{29}$ See, e.g., Allen, Kraakman and Subramanian (2009) at 302-330.

${ }^{30}$ See Laster (2013) at 12-14.

${ }^{31}$ However, Furlow $(2009$, p.571) argues that the Revlon standard should be applied if and only if such potential conflicts of interests are actualized.

${ }^{32}$ Revlon, 506 A.2d at 176.

${ }^{33}$ For details on this point, see Revlon, 506 A.2d at 182.

${ }^{34}$ For what the final-period problem is, see Black and Gilson (1995) at 720. (If the transaction will be repeated, the parties do not tend to have incentives to cheat in this period because the other party in a transaction will retaliate in future transactions. But, if the transaction is at the final period, the parties do not lose incentives to cheat without fearing retaliation in future because there is, by definition, no next transaction.) For the final-period problem in M\&As, see Black and Gilson (1995) at 720 21, Black and Kraakman (2002) at 536, Griffith (2003) at 1945-47, Griffith (2004) at 615-16, Bainbridge (2006) at 789, and Bainbridge (2013) 3291-92.

${ }^{35}$ Laster (2013) at 15-18.

${ }^{36}$ Bainbridge (2013) at 3288-89.
} 
bridge (2013) analyzes the standards of review in Delaware courts as follows: Delaware courts change the standards of review depending on the possibility that the directors' conducts are distorted due to conflicts of interest and how effectively the deterrent mechanism other than law prevents such distorted conduct. ${ }^{37}$ With this framework in mind, he analyzes the situation of the directors facing M\&As. First, if there is no controlling shareholder in the company after an M\&A that is listed on the stock exchange, there is no final-period problem because such a company can be targeted by hostile takeovers. Thus, the market for corporate control (which is a deterrent mechanism other than law) constrains the problem of conflicts of interest, and, the Revlon standard is not necessary in this case. ${ }^{38}$ Second, if there is no controlling shareholder in the company after an M\&A that is not listed on the stock exchange, the directors of the target company might prioritize the acquirer's interests at the expense of the target company's shareholders' interests. Also, if there is a controlling shareholder in the company after the M\&A, the market for corporate control does not work in such a company because the controlling shareholder has de facto power to stop hostile takeovers. In these cases, the problem of conflicts of interest is more serious. ${ }^{39}$ Therefore, Bainbridge argues that the Revlon standard, which is stricter than the Unocal standard, ${ }^{40}$ should be applied in these cases. ${ }^{41}$

On the other hand, Gevurtz (2013) argues that that the Revlon standard is not necessary because the traditional fiduciary duties and the Unocal standard work well as a standard of review against potential conflicts of interests. He indicates that the directors, in Revlon, breached their duties not because they breached the special duty, but because they prioritize the debt holders' interests, which is not consistent with the principle of maximizing shareholders' interests. ${ }^{42}$ Moreover, he argues that if there are direct conflicts of interest, the duty of loyalty offers the adequate standard of review, and, thus, the Revlon standard is not necessary. Furthermore, he points out that if there are any potential conflicts of interest, the Unocal standard is sufficient to deal with them. ${ }^{43}$ Actually, if the Unocal standard cannot work effectively in cases with the final-period problem, the Revlon standard might be necessary. However, Gevurtz claims that the final-period problem is no more serious than the conflicts of interest in the hostile takeovers where the Unocal standard is applied, and, therefore, that the Revlon standard cannot be justified because of the final-period problem. The problem of conflicts of interest among directors facing a hostile takeover is the most serious because the directors have incentives to pursue their personal benefits at the expense of shareholders' interests to receive a premium from the hostile bidder, while the directors with the final-period

\footnotetext{
${ }^{37}$ Bainbridge (2013) at 3303.

${ }^{38}$ Bainbridge (2013) at 3307.

${ }^{39}$ Bainbridge (2013) at 3310-11.

${ }^{40}$ Unocal Corp. v. Mesa Petroleum Co., 493 A.2d 946 (Del. 1985). Under the Unocal standard, the business judgment rule is applied if the directors show the following two requirements: (1) there is reasonable rationale for the board of directors to believe that the takeover threatens the corporate policy or effectiveness; (2) the defensive measures the directors choose are rational concerning such threat.

${ }^{41}$ Bainbridge (2013) at 3335.

${ }^{42}$ Gevurtz (2013) at 1530, 1546-49.

${ }^{43}$ Gevurtz (2013) at 1562-64.
} 
problem in friendly M\&As do not have such incentives, but just lose the incentives to take good options. ${ }^{44}$

What do we learn from this controversy? First, there are no opponents against the view that the problem of potential conflicts of interest occurs in M\&As, and the standard of review on directors' conduct should be stricter than the business judgment rule if such a problem is imminent.

Second, the degree of conflict of interest depends on the circumstances. For example, stock-for-stock mergers between listed companies have few problems of conflicts of interest, while MBOs have serious problems of direct conflicts of interest. Although Laster (2013) argues that the Revlon standard should be applied to all cases of negotiated M\&As, I beleive the idea of applying it to cases with only indirect and potential conflicts of interest is not persuasive. Rather, the claim of Furlow (2009) that the Revlon standard should be applied if and only if such potential conflicts of interest are actualized is more persuasive.

Third, there is a dispute on whether the problem of conflicts of interest is more serious in cases where potential conflicts of interest are actualized by, for example, choosing the acquirer who gives the executive positions in the surviving company to the directors of the target company, than in cases where the board of directors of the target company facing a hostile takeover install a defensive measure against such a takeover. Although Gevurtz (2013) answers negative to this question, the answer should depend on whether the market for corporate control constrains the conduct of directors of the target company, as Bainbridge (2013) indicates. Speaking of defensive measures, the market for corporate control maintains its function as far as the target company keeps its listing on the stock exchange, because the defensive measures can be enjoined by the court. Thus, the hostile bidder has a chance to succeed in the takeover even if the target company takes defensive measures. On the other hand, the market for corporate control will not constrain directors if the surviving company is not listed on the stock exchange, or if the surviving company is controlled by a controlling shareholder. The court cannot mandate the controlling shareholder of a target company to sell its shares to a hostile bidder. Therefore, the hostile bidder has no chance to succeed in the takeover without the consent of the controlling shareholder of the target company. Because the problem of the conflicts of interest in the latter cases is more serious than that in the former case, the Revlon standard is necessary.

\section{(3) Summary}

The examination of the controversy on where to apply the Revlon standard in Delaware stops here because the purpose of this paper is not to settle it. However, what we can learn from this controversy is two-fold. First, the principle of maximizing shareholders' interests is not definitive in such an issue. The discussion takes a practical approach to the issue of what standard of review should be applied to cases entailing the problem of conflicts of interest. Second, the diverging point of the controversy is not whether the business judgment

\footnotetext{
${ }^{44}$ Gevurtz (2013) at 1566-70.
} 
rule should be applied, but whether the Revlon standard should be added to the standards of review, like the Unocal standard. This indicates that just paying attention to the problems of conflicts of interest in M\&As is not sufficient. It is important to structure the legal system with other cases in mind, such as cases with the traditional conflicts of interest where the duty of loyalty is applied, and cases where the defensive measures against hostile takeovers are installed. These points would be useful for analyzing Japanese law.

\section{Comparative Law Analysis}

\section{III-1. Comparison of the Judicial Doctrine in Japan and Delaware}

\section{III-1-1. Relationship with the Principle of Maximizing Shareholders' Interests}

As found in the previous section, the principle of maximizing shareholders' interests does not determine the directors' duty or its standard of review regarding the fairness of the sale price. The argument against imposing duties concerning the fairness of the sale price on directors because of incompatibility with the principle of maximizing shareholders' interests is not persuasive because it is just deducted, without focusing on the characteristics of the cases of the M\&As, from such a principle which is not necessarily valid to cases of M\&As. The principle of maximizing shareholders' interests should determine the fiduciary duties only in the cases where directors determine normal business matters that are very different from M\&As. While the principle of maximizing shareholders' interests is the theory about how to increase their portion of the company's pie, the duties concerning the fairness of the sale price is a system about how to share such a pie. We need not review these two cases under a single standard.

Because M\&As are one kind of strategic tool, directors should enter into M\&As if and only if they increase the long-term interests of the corporation. Whether M\&As increase the long-term interests is the question which the principle of maximizing shareholders' interests asks. Thus, the standard of review about this question should be the business judgement rule, as is often the case where the principle of maximizing shareholders' interests governs. Actually, Tokyo High court applied the business judgement rule in examining the directors' duties on entering into the going-private transaction (in this case, MBO). ${ }^{45}$ This holding distinguishes the validity of entering into an $\mathrm{MBO}$ from the fairness of the sale price, which is consistent with the argument of Johnson and Ricca (2014) and different from Delaware cases which apply the Revlon standard under which the Delaware court does not distinguish these two factors.

Furthermore, in discussing the directors' duties on the fairness of the sale price, the Tokyo High Court assumes that the shareholders are the current ones, not abstract future ones, which is consistent with the Revlon standard as the previous section explained. Tokyo High

\footnotetext{
45 Anonym v. Reins International Inc., 2190 Hanrei Jiho 96 (Tokyo High Ct., Apr 17, 2013) ("Directors entering into the management buyout which is useful to increase the corporate value do not breach their duties of care unless it violates the law, or the directors' such business judgement is too irrational viewed form the surrounding various factors such as the corporation's business conditions").
} 
Court justified the directors' duty to transfer the "fair corporate value" to shareholders because directors' duties are for increasing shareholders' common interests, and shareholders commonly have interests to receive a fair premium from the MBO. The "shareholders" in this logic must be the present ones; otherwise this proposition is not valid because the future shareholders (or, the acquirer) have no reason to receive any premium from such an MBO.

\section{III-1-2. The Fairness of the Sale price}

\section{(1) What is common between Japan and Delaware}

Both the holding of the Tokyo High Court and the Revlon standard in Delaware require the directors of a target company to make the sale price fair. Although the formulizations of the doctrines are not perfectly the same in the strict sense, the basic ideas are alike. While the directors must obtain the highest price reasonably available under the Revlon standard, the Tokyo high court requires the directors to obtain a fair price which is the sum of the corporate value before the MBO plus an adequate premium. Although wording such as "reasonably available" and "adequate premium" are not clear, both formulas are very similar.

\section{(2) What is different between Japan and Delaware}

The holding of the Tokyo High Court is different from that of the Revlon standard in Delaware in two ways: Tokyo High Court (1) weighs shareholders' intention in reviewing the directors' duties, and (2) focuses on the objective valuation of the corporation rather than the fairness of the dealing process of the M\&As.

First, Tokyo High Court held that whether the price reflects the fair corporate value is deferred to shareholders' intention through the resolution of a shareholders' meeting or the number of shareholders who tender their shares in the tender offer, given that the shareholders are adequately informed. Moreover, in dicta, it held that when the shareholders' meeting resolved that the $\mathrm{MBO}$ be authorized, such a resolution works for denying the breach of the directors' duty to transfer the fair corporate value to shareholders even if the price is lower than the objective value of the corporation. ${ }^{46}$ Deferring to shareholders' interests in reviewing the directors' duties regarding the fairness of the sale price is a peculiarity of the Tokyo High Court because Delaware Court is highly unlikely to deny the breach of Revlon duties because many shareholders tendered their shares to the acquirer in the tender offer, which is examined thoroughly in court.

Second, Tokyo High Court focuses on whether the price offered to shareholders in the $\mathrm{MBO}$ is lower than the objective corporate fair value of the target company based on the fairness opinions, rather than whether the dealing process was fair by introducing some measures to intercept it from the influence of conflicts of interest. The Japanese Courts appear to believe that it is necessary to review the sale price itself in determining whether a director has breached the fiduciary duty regarding an M\&A, while the Revlon standard focus-

\footnotetext{
${ }^{46}$ This is dicta because the Tokyo High Court did not respect the shareholders' intent because it found that adequate information was not provided to shareholders.
} 
es on the examining the process of the transactions rather than the price itself.

\section{III-2. Analysis from a Broader Point of View}

Why does the Tokyo High Court defer to shareholders' interests in reviewing the directors' duties regarding the fairness of the sale price? Why does it focus on the price itself rather than the dealing process? As the literature on the Revlon standard showed, analyzing the law from a broader point of view by taking adjacent legal systems into account would be helpful. Thus, this subsection considers these factors.

\section{III-2-1. Rules on New Share Issues}

Both M\&As and the issuance of new shares impact shareholders' rights. Some argue that these "ownership issues" are reviewed under a stricter standard than "enterprise issues" such as the ordinary business judgment. ${ }^{47}$ Thus, to consider the rules on new share issues would be one clue to determine how the fiduciary duties regarding the M\&As should be. Japan's Companies Act provides two special rules on the issuance of new shares: the rule on the especially preferable issuance of new shares and the rule on the unfair issuance of new shares. The requirements to enjoin such new share issues are more shareholder-friendly than ordinary business judgement.

\section{(1) Rule on the Especially Preferable New Share Issue}

Japan's Companies Act allows a company to issue new shares at a preferable price to someone who undertakes to invest in the company even if such new share issues dilute the economic value of the existing shareholders' shares, if and only if a shareholders meeting permits it by a special resolution. ${ }^{48}$ Although such a new share issue sacrifices the current shareholders' short-term interests, it might increase the shareholders' long-term value by investing the money which the company acquired through such a new share issue, which may justify the especially preferable share issue. Then, we can argue that the directors' duty is for increasing shareholders' long-term interests, which does not prohibit the directors from issuing new shares at a price lucrative enough to sacrifice the existing shareholders' interests. Japanese corporate law gives shareholders, rather than the directors, the right to choose whether to sacrifice the short-term interests and increase the long-term value through the preferable share issue. ${ }^{49}$ Of course, whether this policy is good or not is debatable. ${ }^{50}$

The directors' fiduciary duty regarding a preferable new share issue is not clear. Especially, the literature rarely analyzes it by distinguishing the long-term interests from the short-term interests. One of the reasons why this is not studied very much would be that the Japanese corporate law on the preferable new share issue focuses on the question of whether

\footnotetext{
47 See Manning (1985) and Furlow (2009).

48 Sec. 201 and 199(3) of Companies Act of Japan.

49 See Matsui (2004) at 371.

${ }^{50}$ Matsui (2004) criticizes the policy to give such a right to decide it to the shareholders.
} 
the price of the new share issue is as lucrative as the law requires a special resolution of a shareholders' meeting, rather than whether the directors breached their duties. In the typical case, the shareholder-plaintiff claims that the new share issue without a shareholders' meeting's resolution is illegal because it is allegedly too lucrative. Under this setting, it is whether the shareholders' meeting authorizes it that is the issue for the court to focus on. If the shareholders' meeting authorizes it, there is no room to enjoin it, which makes it meaningless to ask whether the directors breached the duties. ${ }^{51}$

This discussion is in line with the Tokyo High Court's approach to defer shareholders' intent in reviewing the duty to transfer the fair corporate value to shareholders in the MBO. The basic idea that the directors are not deemed to have breached the duties if the shareholders authorize the directors decisions is common in these two cases: when the shareholders' meeting authorizes the lucrative new share issue and when the shareholders' meeting authorizes the M\&As even if its price is lower than the objective corporate value, as the Tokyo High Court implicated.

\section{(2) Rule on Unfair Share Issue as a Defense Against a Hostile Takeover}

A typical defensive measure against a hostile bidder is a new share issue to someone who takes the current management team's side. Thus, the bidder brings the case into the court for obtaining an injunction against such new share issue because of the unfair issuance of new shares. Japanese corporate law provides that shareholders are able to enjoin the unfair new share issue. ${ }^{52}$ One of the requirements of such an injunction is that such a new share issue is too unfair while the breach of the director's duty is not its requirement, which is different from Delaware law, where the breach of the director's duty is the main requirement to enjoin a defensive measure such as poison pills. Thus, in Japan, the director's duty regarding defensive measures against hostile takeovers is not clear because the court facing such a case does not need to show what the director's duty is.

Japan's court generally shows a skeptical attitude toward defensive measures against a hostile takeover. It tends to discuss the case from the viewpoint of the distribution of power between the board of directors and shareholders, and think that shareholders have the power to choose who the directors should be, ${ }^{53}$ and, thus, the directors are not allowed to issue a new share for a defensive measure unless there are special exceptional circumstances around such a hostile bidder such as the fear of looting the company. ${ }^{54}$ The courts have also applied the "primary purpose test," under which the new share issue is unfair if its primary purpose is to decrease the ratio of the hostile bidder's shareholding in order to keep control of the current management in cases where the corporate control is contested and the amount of the issuance of the new share is significant. ${ }^{55}$ Under these standards of review on the unfair new

\footnotetext{
${ }^{51}$ The directors might breach the duty if is made the bad business judgment when using the money collected through the new share issue. See Matsui (2004) at 394-395.

${ }^{52}$ Sec. 210 of Companies Act of Japan.

53 See, e.g., Livedoor v. Nippon Broadcasting, 1899 Hanrei Jiho 56 (Tokyo High Ct., Mar. 23, 2005).

${ }^{54}$ Id.

${ }^{55}$ Anonym v. Daiya Tsusho, 1400 Kinyuu Shouji Hanrei 52 (Tokyo High Court, July 12, 2012).
} 
share issue, the court does not give as much discretion to the directors as under the business judgment rule. This tendency of the court can be understood as adopting the norm that the degree of the discretion of the directors should be narrowed in cases entailing conflicts of interest where the directors want to defeat the hostile bidder to protect their position even if such a hostile bid is beneficial to shareholders.

Many defensive measures in Japanese companies have been confirmed by shareholders' meetings ex ante at the stage without any imminent threat of potential hostile bidders. Furthermore, the Supreme Court of Japan weighs the resolution of a shareholders' meeting to confirm the defensive measure: it held that if the shareholders' meeting authorizes the defensive measure because the hostile bidder would damage the target company's value, such a defensive measure is not subject to an injunction. ${ }^{56}$ That is, the court refrains from interfering with shareholders' intent on whether the hostile bidder harms the corporate value of the target company. One could argue that there is no breach of the director's duty concerning the installment of the defensive measure which is affirmed by shareholders' meeting, as it is implicitly taken for granted.

The structure of such thinking is as follows. Shareholders of the target company face the situation where they must choose one of two alternatives: to take the tender offer price offered by the hostile bidder (short-term interests) or to take the benefits from the continuance of the current management (long-term interests). The directors of the target company might think that the latter is bigger than the former, and propose to have the defensive measure. Of course, we cannot take their decision at its face value because there is a problem of conflicts of interest in the cases of hostile takeovers. However, the confirmation at a shareholders' meeting is free from such conflicts of interest which could possibly distort the director's decision. Furthermore, one can say that it is even natural to follow the shareholders' decision because choosing between these two alternatives is similar to electing the directors from two contesting teams. This thought is consistent with the characteristics of the Tokyo High Court's decision.

\section{III-2-2. Rule on the Transactions Entailing Conflicts of Interests}

The corporate law of Japan provides a special rule concerning the requirement of the process of the transaction with conflicts of interest and the liability of the director who entered into such a transaction. If the director deals with its corporation, such a director must disclose the material facts to the board of directors and get the affirmation of the board of directors. ${ }^{57}$ After closing such transaction, the director must report the material facts to the board of directors. ${ }^{58}$ Furthermore, the burden of the proof that the director breached the duty is changed from being on shareholders to on the director. If the company suffers from the transaction with its director, the director is presumed to have breached its duty unless she proves that she did not. ${ }^{59}$ In addition, while, in ordinary cases, the directors' liability is ex-

\footnotetext{
${ }^{56}$ Steel Partners Japan v. Bulldog Sauce, 61 Minshuu 2215 (Supreme Court, Aug. 7, 2007).

${ }^{57}$ Sec. 356 (1) of Companies Act of Japan.

${ }^{58}$ Sec. 356 (2) of Companies Act of Japan.
} 
empted if she is not negligent, such an exemption is not available for a director who is the counter partner of the transaction with the corporation. ${ }^{60}$

This rule on transactions entailing conflicts of interest in Japan is different from Delaware law in three senses. First, this rule does not cover the MBO where the directors and shareholders are the parties to a transaction because the above-stated rule in Japan is only applied to transactions between directors and a corporation as opposed to shareholders. However, because the business judgment rule is not applicable to cases involving the problem of conflicts of interest, ${ }^{61}$ the director's liability is found in cases entailing such problem more often than in other cases.

Second, while, in Delaware, the approval of the transaction entailing conflicts of interest with the disclosure of the material facts by the board of directors triggers the application of the business judgment rule, it does not in Japan. The liability of the director in Japan is stricter than that in Delaware.

Third, as section 423 (3) of the Companies Act of Japan, which shifts the burden of proof, is applied when the corporation suffers from a loss, it takes the approach to focus on whether there is any loss in the company. In other words, the dealing process of the transaction involving conflicts of interest is not necessarily the key to determine whether the director is liable. ${ }^{62}$

As explained above, focusing on the loss or the transaction price itself rather than the dealing process in the cases of the transaction entailing conflicts of interest is in line with the Tokyo High Court's approach to review its case by focusing on the sale price itself.

\section{III-2-3. Interpretation of the Appraisal Right}

The court, in the appraisal right cases, is supposed to be (or has to be) able to make judgments of the fairness of the price. This thinking is in line with the Tokyo High Court's approach to focus on the price itself in reviewing the director's duty to transfer the fair corporate value to shareholders. The concepts of Tokyo High Court, such as "fair corporate value" and "the value the MBO creates to be given to the shareholders" would be derived from the interpretation of the appraisal right. ${ }^{63}$ This adds the evidence that the approach the Tokyo High Court took is in line with the debate on the appraisal right.

Furthermore, the argument that the court should examine the measure to insulate the transaction from the influence of conflicts of interest in determining the fair value in the appraisal right cases is widely supported by most scholars and courts. If such a measure is installed, the court should mandate companies to buy dissenting shareholder's shares at the same price as other shareholders receive in such a merger. ${ }^{64}$ This is a new idea for Japanese corporate law because the rule on the conflicts of interest, as explained above, does not

\footnotetext{
${ }^{59}$ Sec. 423 (3) of Companies Act of Japan.

${ }^{60}$ Sec. 428 (1) of Companies Act of Japan.

${ }^{61}$ Tatsuta (2007) at 93.

${ }^{62}$ Ochiai (2014) criticizes the Japanese law because it does not require the board of directors to be independent.

${ }^{63}$ See Iida (2013) at 11-12.

${ }^{64}$ See Iida (2013) at 21.
} 
weigh the dealing process very much.

However, the focus of the issue in appraisal rights is on fair value, not on the breach of the director's duty. Thus, this argument in shareholders' appraisal rights is not necessarily valid in the cases where the duty of the director is at issue.

\section{III-2-4. Discussion}

The corporate law in Japan and Delaware makes strict rules on conflicts of interest such as the rule on transactions entailing conflicts of interest between the director and the corporation, and the rule on defensive measures against hostile takeovers. The distinctive feature of Japanese corporate law on the rule on conflicts of interest is that shareholders' intent is esteemed and that the court focuses more on the existence of a loss the corporation suffers from a transaction involving conflicts of interest than the fairness of the dealing process such as installing a measure to insulate the influence of conflicts of interest.

The holding of the Tokyo High Court in the MBO case is conformable to the feature of Japanese corporate law. Mandating the directors to pay attention to the fairness of a price for shareholders' short-term interests is not directly drawn from the principle of maximizing shareholder value, but is in line with the Japanese corporate law's strict attitude against the conflicts of interests. Esteeming shareholders' intent on the propriety of directors' decision concerning short-term interests is found not only in the MBO case, but also in the rules on the new share issue. Reviewing the transaction price itself rather than the adequacy of the dealing process is consistent with the rule on the related-party transaction under which the law presumes that the directors breached their duties if the corporation suffers the loss. Believing that the judges are capable of determining the fair corporate value and the fair premium is common not only in the fiduciary duties case, but also in the rule on the appraisal right.

In contrast, the Delaware courts do not esteem shareholders' intent in reviewing the Revlon duty. This is consistent in Delaware law which does not have a special rule on preferable new share issues, unlike Japanese law. Of course, the Unocal standard applicable to defensive measures against the hostile takeovers is for assuring the opportunity for shareholders to make decisions. However, it allows the board of directors of a target company to decide whether such a takeover is a threat to the company and does not require the board to ask shareholders about it. This is quite different from Japanese law, which usually requires the board to ask shareholders whether to implement defensive measures, and reviews it by applying the stricter rule on unfair new share issues if there is no shareholders' resolution about it. Also, that the process of the transaction is the key factor in the review of Revlon duties is consistent with the rule on the related-party transaction which focuses on measures against conflicts of interest, such as the approval of independent directors or shareholders. Taken this legal system into account, we can understand the argument of Gevurtz (2013) to abolish the Revlon standard because the Revlon standard adds little to the existing system of directors' duties. 


\section{Conclusion}

This paper studied the relationship between Revlon duties and the principle of maximizing shareholders' value and clarified the features of corporate law in Japan and Delaware. The duty to transfer fair corporate value to shareholders is consistent with the traditional system of corporate law in Japan. Thus, if one wants to criticize such a duty, it is necessary to reform the system of corporate law regarding the rules this paper analyzed. If one wants to install the approach to pay more attention to the fairness of the dealing process, the same approach should be installed into the rules on related-party transactions at the same time. If one wants to criticize the approach to esteem shareholders' intent, one needs to distinguish the issue on the fairness of the sale price from the issue on the rule on new share issues. In sum, because the director's duty works in the balance of the adjacent legal system, it is impossible to change the contents of the director's duty alone. If reforming the director's duty is necessary, the rules on the related-party transaction, the new share issue and the appraisal rights must be reformed at the same time. This is left for future work.

Furthermore, it is important to study the director's duty which is the most efficient rule on M\&As. If the content of the director's duty is too rigorous, the directors will refrain from entering into M\&As which would be efficient for the corporation but not for the directors, due to fearing personal liability. If the content of the director's duty is too lax, the directors would enter into M\&As even when they are inefficient. Thus, making the director's duty optimal is important. This paper contributes to this task by clarifying the legal background to the director's duty.

\section{References}

Allen, William T., Kraakman, R. and Subramanian, G. (2009), Commentaries and Cases on the Law of Business Organization, $3^{\text {rd }}$ ed., Wolters Kluwer.

Bainbridge, S.M. (2006), "Unocal at 20: Director Primacy in Corporate Takeovers," Delaware Journal of Corporate Law, Vol. 31 No. 3, pp.769-863.

Bainbridge, S.M. (2013), "The Geography of Revlon-Land,” Fordham Law Review, Vol. 81 No. 6, pp.3277-3338.

Bebchuk, L.A. (2013), “The Myth That Insulating Boards Serves Longterm Value," Columbia Law Review, Vol. 113 No. 6, pp.1637-1694.

Black, B., and R. Kraakman (2002), "Delaware's Takeover Law: The Uncertain Search for Hidden Value," Northwestern University Law Review, Vol. 96 No. 2, pp.521-566.

Black, B.S., and R.J. Gilson (1995), The Law and Finance of Corporate Acquisitions 2nd Ed. Foundation Press.

Furlow, C.W. (2009), "Reflections on the Revlon Doctrine," University of Pennsylvania Journal of Business Law, Vol. 11 No. 3, pp.519-572.

Gevurtz, F.A. (2013), "Removing Revlon," Washington \& Lee Law Review, Vol. 70 No. 3 , 
pp.1485-1571.

Griffith, S.J. (2003), “Deal Protection Provisions in the Last Period of Play," Fordham Law Review, Vol. 71 No. 5, pp.1899-1970.

Griffith, S.J. (2004), “The Costs and Benefits of Precommitment: An Appraisal of Omnicare V. Ncs Healthcare," Journal of Corporation Law, Vol. 29 No. 3, pp.569-623.

Iida, H. (2013), "Kabushiki Kaitori Seikyuuken no Kouzou to Kaitori Kakaku Santei no Kouryo Youso," Shouji Houmu.

Iida, H. (2014), "Rex Holdings Songai Baishou Seikyu Jiken Kousai Hanketsu no Kentou [Ge]," Shouji Houmu No. 2023, pp.17-26.

Iwakura, M. and Ishikawa, T. (2010), "Torishimariyaku no Sekinin Koudou Junsoku-Waga Kuni ni oite Revlon Gimu ha Mitomerareruka," Iwakura, M. and Ohta Y. eds, M\&A Houmu no Saizensen, Shouji Houmu.

Johnson, L., and R. Ricca (2014), “The Dwindling of Revlon," Washington \& Lee Law Review, Vol. 71 No. 1, pp.167-227.

Kawashima, I. (2014), “Case Note,” Hanrei Hyouron No. 663, pp.32-36.

Laster, J.T. (2013), "Revlon Is a Standard of Review: Why It's True and What It Means," Fordham Journal of Corporate \& Financial Law, Vol. 19 No. 1, pp.5-55.

Manesh, M. (2014), "Defined by Dictum: The Geography of Revlon-Land in Cash and Mixed Consideration Transactions," Villanova Law Review, Vol. 59 No. 1, pp.1-34.

Manning, B. (1985), "Reflections and Practical Tips on Life in the Boardroom after Van Gorkom," Business Lawyer, Vol. 41 No. 1, pp.1-14.

Matsui, H. (2004), "Shinkabu Yuuri Hakkou Kisei ni kansuru Ichi Kousatsu," Kozuka, S. and Takahashi, M. eds, "Shoujihou he no Teigen," Shouji Houmu.

Miller, R.T. (2013), "Inefficient Results in the Market for Corporate Control: Highest Bidders, Highest-Value Users, and Socially Optimal Owners," Journal of Corporation Law, Vol. 39 No. 1, pp.71-128.

Ochiai, S. (1998), "Kigyou Hou no Mokuteki - Kabunusi Rieki Saidaika Gensoku no Kentou”, Iwamura, M. ed. "Gendai no Hou 7 • Kigyo to Hou," Iwanami Shoten.

Ochiai, S. (2014), "Kaisha Hou no Rieki Souhan Kisei no arikata," Kinyuu • Shouji Hanrei No. 1431, p.1.

Ohta, Y. and Yano, M. (2010), “Taikouteki Baishuu Teian wo uketa Taishou Kaisya Torishimariyaku ha ikani Koudou subekika - Waga Kuni Kaisya Hou to Revlon Gimu," Iwakura, M. and Ohta Y. eds, M\&A Houmu no Saizensen, Shouji Houmu.

Roe, M.J. (2013), "Corporate Short-Termism - in the Boardroom and in the Courtroom," Business Lawyer, Vol. 68 No. 4, pp.977-1006.

Saito, M. (2014), "Case Note”, Hanrei Select 2013 [II], p.19.

Shirai, M. (2013a), "Yuukou Teki Baishuu no Bamen ni okeru Torishimariyaku ni taisuru Kiritu," Shouji Houmu.

Shirai, M. (2013b), "Rex Holdings Songai Baishou Seikyu Jiken Kousai Hanketsu no Kentou," Business Houmu Vol. 13 No. 11, pp.46-52.

Tanaka, W. (2012), "Kigyou Baishuu to Boueisaku," Shouji Houmu. 
Tatsuta, M. (2007), "Kaishahou Taiyou," Yuhikaku.

Yanaga, M. (2013), “Case Note,” Jurisuto No. 1456, pp.2-3. 